\title{
Open Access Electronic Resources Use and Research Productivity of Faculty Members: A Case Study of a Selected University in Ghana
}

\author{
Ellen Amponsah ${ }^{1, *}$, E. Madukoma ${ }^{2} \&$ V. E. Unegbu ${ }^{2}$ \\ ${ }^{1}$ Valley View University, P. O. Box AF 98, Oyibi-Accra, Ghana \\ ${ }^{2}$ Department of Information Resources Management, Babcock University, ILishan-Remo, Nigeria \\ *Correspondence: Valley View University, P. O. Box AF 98, Oyibi-Accra, Ghana. Tel: 233-246-812-882. E-mail: \\ elleamps@gmail.com
}

Received: September 28, 2021

Accepted: November 26, $2021 \quad$ Online Published: December 6, 2021

doi:10.5430/wje.v11n6p18

URL: https://doi.org/10.5430/wje.v11n6p18

\begin{abstract}
Research is one of the key pillars in the teaching and learning situation in any university in the world. However, the approach to research varies from one university to the other. The purpose of this study was to find out how the level of awareness and satisfaction, the challenges and extent of use of open access resources impact research productivity of faculty in *Dartum University. A quantitative survey research method was adopted. A sample size of 62 full-time lecturers and 134 part-time lecturers was selected for the study using a stratified simple random sampling technique. The findings revealed that research productivity is low despite the high level of awareness and satisfaction with open access use. Again, the findings showed that faculty members use open access to a considerable extent and point out some challenges associated with open access use. It was concluded that there is a very weak but significant influence of open access use on research productivity in Dartum University. It is recommended that African universities, and in particular Dartum University, establish or patronise institutional repositories which support open access.
\end{abstract}

Keywords: research productivity, electronic resources, open access, faculty productivity

\section{Introduction}

Over the past few years, there has been a tremendous increase in the emphasis on research productivity in universities. Alongside teaching, research and publication output have become tools for measuring performance among universities (Ram \& Paliwal, 2016). The high emphasis on research is because of changes in government research funding patterns, nationwide research assessments and international league tables. Around the world, research productivity in universities is gaining a lot of attention mostly among researchers, administrators, scientists and policy makers. In the current academic setting, one main way of measuring academic success is the ability to publish in high status refereed journals. Many Universities encourage research by remunerating the faculty members for research productivity (Brew, Boud, Namgung, Lucas \& Crawford, 2015).

Research Productivity commonly refers to the number of publications per researcher. Due to its measurement parameters, research productivity is very difficult to measure. There have been attempts by bibliometrics to come up with accurate and reliable research indicators, however, such attempts have only caused an increasing confusion (Abramo \& D'Angelo, 2014). When it comes to measurement of research productivity, "one size does not fit all." It is easier to measure articles published in mainstream scientific journals than books, online and open access publications (Altback, 2014). In this article, measurement of faculty productivity was limited to research publications.

Studies indicate that research productivity in Africa is relatively low (Lertputtarak 2008). Maasen (2015) describes African universities as lagging behind as far as research productivity is concerned, despite the presence of highly productive scholars and academics. This is attributed to economic reasons and research strategies and practices in African universities. In the Sub-Saharan Africa, research productivity differs from country to country just like its diverse cultural and economic profiles (Saric, Utzinger, \& Bonfoh, 2018). In Ghana, university education is on the rise. As at 2017, there were 10 public universities, 4 private universities which were chartered, 72 private university 
colleges, 10 polytechnics of which some have been converted to technical universities, 29 nurses training colleges and 45 colleges of education (Alabi \& Mohammed, 2018). Though the number of universities has increased, according to Alabi and Mohammed (2018), research production is very low, but efforts are being made towards its expansion. Utulu (2005) and Ogbomo (2010) mentioned some hindering factors to research productivity. Among them are failure to understand the purpose of publication, lack of funds, lack of time, ignorance of where to publish and many more.

To increase research productivity, there is a need for researchers to gain access to good journals. With most universities' inability to fund subscriptions to good electronic journals, reliance on predatory journals has become rampant. Though open access resources come with several benefits, there are also some predatory features too. In Africa, most people in the field of academia have resorted to the use of and reliance on predatory journals which publish in large volumes whiles transgressing the research integrity rules. This has put the integrity of universities into question and must therefore be taken seriously by academicians and universities at large. To improve upon this situation, there has been calls by people in academia to enact more policies to enhance the existing policies. In Ghana, there are two bodies, which regulate the higher education sector: The National Accreditation Board which plays the role of accrediting private and public institutions and ensuring that all institutions meet professional standards in teaching and research; and the National Council for Tertiary Education which provides advisory services to the ministry of education on tertiary institution development, formulates policies to regulate institutions and also plays a role in financing and budgeting for the sector (Alabi \& Mohammed, 2018).

The productivity level of faculty at Dartum University in the area of open access resources takes into consideration the level of awareness and satisfaction towards faculty, their frequent or otherwise use of open access electronic resources, the purpose for using open access electronic resources, how the use of open access electronic resources significantly influence faculty members' research productivity and finally the challenges to faculty's use of open access e-resources.

In the western part of Africa where financial hardship is so much of an issue to battle with, subscription to a good number of journals in order to have access to publications is not so affordable for many researchers. Some institutions such as universities try their best to subscribe to a number of journals for their faculty and students to have access. These institutions, however, do not have much funds. As a result, the journals they are able to subscribe to are but a few. This greatly affects the extent to which most faculty in Africa are able to get access to new publications and new developments in their areas of interest. This seems to have adverse effect on their productivity in research.

Though several studies have been conducted on research output and open access resources, according to Iddris (2017), there is not much research on the research output of faculty in universities in Ghana. The researcher has also identified that studies on research productivity and open access is lacking at Dartum University even though open access is used by faculty. Therefore, this study seeks to determine the influence of open access electronic resources use on the productivity of faculty members of Dartum University, Ghana. The specific objectives are to: 1) determine the research productivity level of faculty members, 2) determine the level of awareness and satisfaction towards open access resources, 3) examine the extent to which faculty members use open access electronic resources, 4) examine the purpose for using open access electronic resources, 5) examine how the use of open access electronic resources will significantly influence faculty members' research productivity, and 6) identify the challenges to faculty's use of open access e-resources.

\subsection{Research Hypotheses}

The following hypotheses guided the research which was measured at 0.05 significance level:

$\mathrm{H}_{0}$ : The use of open access electronic resources will not significantly influence the research productivity of Dartum University faculty members.

H1: The use of open access electronic resources will significantly influence the research productivity of Dartum University faculty members.

In these hypotheses testing, a number of factors were taken into consideration. It is established that faculty of Dartum University use open access resources and their level of awareness and satisfaction, the extent of use of open access electronic resources, the purpose for using open access electronic resources is very high.

\subsection{Concept of Open Access Electronic Resources}

The concept of open access is today widely recognized amongst various researchers of diverse geographical 
locations and fields of research. Open access, according to Suber (2015), refers to electronic, online digital, unrestricted and free of most limitations on copyright and licensing. Although open access is a term mostly used to apply to online publications, nonetheless, journals with printed versions have their compatibility with open access. According to Morrison (2012), just as other concepts, open access has much to it than portrayed in its definitions. It has many concepts embedded in it. To fully comprehend the discussions of open access, it is necessary to have the knowledge about lobby and its tactics by influential, powerful and wealthy publishers, which further complicates and as well opposes to the idea of open access (Guedon, 2015, Morrison, 2012).

\subsection{Types of Open Access Resources}

Studies suggest that there are two different forms of open access available (Musa, Sanusi, Yusuf, \& Shittu, 2015). The open access journal which is known as the "gold road" and open access repositories or institutional repositories which is the "green road." Examples of open access journals have been developed by the Lund University library, following the First Nordic Conference on Scholarly communication in Lund Copenhagen in 2002. In more specific terms, Harnad (2013) mentions two main ways open access can be provided by authors. They are:

1. The open access publishing (Gold open access): Where articles are published in freely accessible journals online.

2. Open access self-archiving (Green open access): Where articles are published in any random journal, but the final peer-reviewed draft is deposited in an open access repository, so it becomes freely accessible online. Journals with open access follow a peer-evaluation procedure for their content. Many open access journals are published online in order to make their content available freely and free of charge shortly after publication. This is called the "golden road" to open access. Some publishers, including the BioMed Central and the Public Library of Science, are providing open access journals (Kumar \& Bansal, 2008; Pinfield, 2008).

Examples of open acesss journals cut across almost all fields of endearvour. Particular mention of a few of these journals are African Journal of Food, Agriculture, Nutrition and Development (Agriculture), Journal of Korean Astronomical Society (Astronomy), Journal of Open Source Software (Computer Science), Journal of International Students (Education), and Journal of World Systems Research (Social Science)

\subsection{Theoretical Framework}

In this research, two theories were used to assess and support the variables under study. The theories were combined, and the resulting concept aided in conceptualizing how the various variables under study relate to each other. These theories are Social Exchange Theory (SET) and Unified Theory of Acceptance Use of Technology (UTAUT)

\subsubsection{Social Exchange Theory (SET)}

The social exchange theory is a theory that was developed by an American sociologist known as George Homans in 1958. The theory proposes that human social behavior is the result of an exchange process which seeks to minimize costs and maximize profits. The theory stipulates that for people to enter social relationships, they weigh the potential benefits and the risks of that relationship. If the risks outweigh the benefits, they are likely to terminate the relationship and if the benefits outweigh the risks, they are likely to continue to be in the relationship (Crossman, 2020). The theory is commonly used in the field of economics and psychology and other sociologists like Peter Blau in 1964 and Richard Emerson in 1962 (Crossman, 2020) who made major contributions to the theory.

The theory may be used to explain the contribution of scientists to open access. In his study, Kim (2011) related the social exchange theory to open access based on the cost and benefits analysis. He identified costs to include additional effort and time needed to upload research work to open access repositories and also cited copyright concerns. He also cited some benefits including easy accessibility, publicity, increased citation, trustworthiness as a result of peer review and professional recognition. The cost factors inhibit knowledge sharing whiles the benefits promote knowledge sharing. Kim explains the following variables: cost is an additional effort and time with copy right issues and fear of plagiarism; extrinsic benefits refer to academic reward, professional recognition, accessibility, publicity and trustworthiness; intrinsic gains also refer to altruism and self-interest; circumstantial factors relate to self-archiving of culture, influence of external factors and finally, individual traits embody age, professional rank, technical skills.

The cost and benefit factors proposed by the Social Exchange Theory is adopted in the study. A framework which could be used to understand how scientists communicate with systems of open access in the sharing of the results if their research has been provided by the social exchange theory. Nonetheless, other factors like technological infrastructure is not specified by the model. SET could therefore be extended to cover the technological acceptance model, to be able to improve upon the ease of use and factors of usefulness on the use of knowledge repositories by 
the contributions (Kankanhalli, Tan, \& Wei, 2005). The Social Exchange Theory, as explained by Kim (2011), helps in the understanding of how researchers and faculty members share information by means of open access using the cost and benefit factor making it relevant to this present study. Faculty members are likely to use open access for their publications if the benefits of using open access outweigh the costs. In West Africa, where research funding is difficult to come by, open access through Agricultural and Food Science Journal of Ghana, Ghana Journal of Development Studies, Ghana Journal of Forestry, and Ghana Library Journal provides an easier avenue for faculty in their research activities.

\subsubsection{Unified Theory of Acceptance and Use of Technology (UTAUT)}

The Unified Theory of Acceptance and Use of Technology model is a Technology Acceptance Model, which was developed by Venkatesh, Morris, Davis and Davis (2003). The model was developed from eight other Technology Acceptance models which are as follows; "The Theory of Reasoned Action (TRA), Technology Acceptance Model (TAM), the Motivational Model (MM), the Theory of Planned Behaviour (TPB), a blended Theory of Planned Behaviour/Technology Acceptance Model (MPCU), the Innovation Diffusion Theory and the Social Cognitive Theory (SCT)" (Zhou, et al., 2019).

These different models were put together to form the Unified Theory of Acceptance and Use of Technology and it aims to explain the intentions of users in using information systems and their subsequent usage behaviour. The theory holds that there are four main constructs which determine user adoption of technology (Alwahaishi \& Vaclav, 2013). They are as follows: performance expectancy, effort expectancy, social influence and facilitating conditions. This current study hinges on both the social exhange theory and unified theory of acceptance and use of technology.

\section{Methodology}

This article adopted regression analysis in the analysis of data. Regression is an aspect of the quantitative survey that was used as research design in this study. The survey research design was used because it helps to collect a lot of information from a large population within the shortest possible time. The study was carried out at Dartum University and it included all faculty members of the various campuses and centres of the University comprising 389 faculty members. The study included full-time faculty members and part-time lecturers engaged by the university. The population is broken down into campuses and centres as outlined in Table 1:

Table 1. Population of the Study

\begin{tabular}{lccc}
\hline Campus/Centre & Full-Time Lecturers & Part-Time Lecturers & Total \\
\hline Oyibi & 70 & 60 & 130 \\
Techiman & 45 & 50 & 95 \\
Kumasi & 5 & 50 & 55 \\
Tamale & 0 & 40 & 40 \\
Takoradi & 2 & 40 & 42 \\
Swedru & 0 & 15 & 15 \\
City Campus (Accra) & 1 & 11 & 12 \\
Grand Total & 123 & 266 & 389 \\
\hline
\end{tabular}

Source: Dartum Human Resource Department (2019)

\subsection{Sample Size}

Stratified simple random sampling technique was used. The Yamane's (1967) formula, as cited in Osahon and Kingsley (2016), was used to determine the appropriate sample size of 196 respondents (refer to Table 2). The sample size was distributed proportionately across the various campuses and centres using percentages of the total population as indicated in Table 2. In selecting the respondents, a list of all members of the population was made and numbered sequentially according to the various campuses and centres. A random number table was then prepared and used to select respondents. 
Table 2. Sample Size

\begin{tabular}{lcc}
\hline \multirow{2}{*}{ Campus } & \multicolumn{2}{c}{ Respondents } \\
\cline { 2 - 3 } Oyibi & Full Time & Part Time \\
Techiman & 35 & 30 \\
Kumasi & 23 & 25 \\
Tamale & 3 & 25 \\
Takoradi & 0 & 20 \\
Swedru & 1 & 20 \\
City Campus (Accra) & 0 & 8 \\
Total & 0 & 6 \\
\hline
\end{tabular}

A structured questionnaire was developed with the support of experts in the fields of education, library and psychology. The questionnaire was developed taking into consideration the objectives and the research questions of the study. It was this structured questionnaire that was used to collect data for the study. Face and content validity were also done by experts in the fields of education, library and psychology. In addition, construct validity of translating ideas or theories into actual measures was highly considered. To ensure reliability of the research instrument, a pre-test was conducted using 30 lecturers from a selected university other than Dartum University using the reliability coefficients. The reliability test was conducted using a Cronbach's Alpha coefficient of 0.78 using faculty members from the Ghana Christian University College. The collected data was analysed by means of descriptive and inferential analysis. According to Bhatia (2018), descriptive analysis includes the use of modes, percentages and frequencies whiles an inferential analysis includes the use of regression and correlation, which were used in this article.

\subsection{Data Analysis}

The data that were collected from the 196 respondents were inputted into the computer and analysed with the help of the Statistical Package for Social Sciences (SPSS) software version twenty-five. Also, a multiple regression analysis was used to analyse the hypothesis, tested at 0.05 significant level. All the 196 responses were well completed and retrieved from the respondents for analysis. This represented a 100 percent response rate, which is adequate to attain the objectives of the study.

\section{Results}

\subsection{Results Based on the Objectives of the Study}

Objective One: Determining the productivity level of faculty members

Faculty members were asked four major questions intended to obtain information on their productivity. The fourth question had 11 sub-questions, which were intended to find information on the various avenues through which faculty members publish their research work. The analysis of their responses is presented in Table 3.

Table 3 provides an analysis of the publication behaviour of faculty members of Dartum University. A grand mean of 1.48 for publications in various avenues indicates a very low research productivity among faculty members. The table also revealed that only $14.8 \%$ of respondents had more than 10 publications and as much as $56.7 \%$ had total publications of five or less. This indicates a generally low productivity among faculty members. Open access publications were also low with $3.6 \%$ of respondents having more than 10 open access publications and $87.2 \%$ having five or less open access publications. Publications in subscription-based journals was also low with only $2 \%$ of respondents having more than 10 subscription-based publications and $87.7 \%$ having less than six publications in paid journals. 
Table 3. Productivity of Faculty Members

\begin{tabular}{|c|c|c|c|c|c|c|c|c|}
\hline $\mathbf{S} / \mathbf{N}$ & Publications & $\mathbf{0}$ & 1-2 & $3-5$ & 6-10 & $\begin{array}{l}\text { More } \\
\text { than } 10\end{array}$ & Mean & $\begin{array}{l}\text { Standard } \\
\text { Deviation }\end{array}$ \\
\hline 1. & $\begin{array}{l}\text { How many publications have } \\
\text { you produced? }\end{array}$ & $\begin{array}{c}16 \\
(8.2 \%)\end{array}$ & $\begin{array}{c}54 \\
(27.6 \%)\end{array}$ & $\begin{array}{c}41 \\
(20.9 \%)\end{array}$ & $\begin{array}{c}56 \\
(28.6 \%)\end{array}$ & $\begin{array}{c}29 \\
(14.8 \%)\end{array}$ & 3.14 & 1.21 \\
\hline 2. & $\begin{array}{l}\text { How many of your research } \\
\text { work has been published in } \\
\text { open access journals? }\end{array}$ & $\begin{array}{c}52 \\
(26.5 \%)\end{array}$ & $\begin{array}{c}70 \\
(35.7 \%)\end{array}$ & $\begin{array}{c}49 \\
(25.0 \%)\end{array}$ & $\begin{array}{c}18 \\
(9.2 \%)\end{array}$ & $\begin{array}{c}7 \\
(3.6 \%)\end{array}$ & 2.28 & 1.06 \\
\hline 3. & $\begin{array}{l}\text { How many of your research } \\
\text { work has been published in } \\
\text { paid journals? }\end{array}$ & $\begin{array}{c}58 \\
(29.6 \%)\end{array}$ & $\begin{array}{c}70 \\
(35.7 \%)\end{array}$ & $\begin{array}{c}44 \\
(22.4 \%)\end{array}$ & $\begin{array}{c}20 \\
(10.2 \%)\end{array}$ & $\begin{array}{c}4 \\
(2.0 \%)\end{array}$ & 2.19 & 1.04 \\
\hline i. & Articles in learned journals & $\begin{array}{c}45 \\
(23.0 \%)\end{array}$ & $\begin{array}{c}65 \\
(33.2 \%)\end{array}$ & $\begin{array}{c}37 \\
(18.9 \%)\end{array}$ & $\begin{array}{c}29 \\
(14.8 \%)\end{array}$ & $\begin{array}{c}20 \\
(10.2 \%)\end{array}$ & 2.56 & 1.27 \\
\hline ii. & Chapters in books & $\begin{array}{c}111 \\
(56.6 \%)\end{array}$ & $\begin{array}{c}72 \\
(36.7 \%)\end{array}$ & $\begin{array}{c}9 \\
(4.6 \%)\end{array}$ & $\begin{array}{c}4 \\
(2.0 \%)\end{array}$ & $\begin{array}{c}0 \\
(0.0 \%)\end{array}$ & 1.52 & 0.68 \\
\hline iii. & Conference proceedings & $\begin{array}{c}92 \\
(46.9 \%)\end{array}$ & $\begin{array}{c}77 \\
(39.3 \%)\end{array}$ & $\begin{array}{c}14 \\
(7.1 \%)\end{array}$ & $\begin{array}{c}7 \\
(3.6 \%)\end{array}$ & $\begin{array}{c}6 \\
(3.1 \%)\end{array}$ & 1.77 & 0.95 \\
\hline iv. & Occasional papers & $\begin{array}{c}122 \\
(62.2 \%)\end{array}$ & $\begin{array}{c}56 \\
(28.6 \%)\end{array}$ & $\begin{array}{c}11 \\
(5.6 \%)\end{array}$ & $\begin{array}{c}4 \\
(2.0 \%)\end{array}$ & $\begin{array}{c}3 \\
(1.5 \%)\end{array}$ & 1.52 & 0.82 \\
\hline v. & Co-authored textbooks & $\begin{array}{c}152 \\
(77.6 \%)\end{array}$ & $\begin{array}{c}38 \\
(19.4 \%)\end{array}$ & $\begin{array}{c}6 \\
(3.1 \%)\end{array}$ & $\begin{array}{c}0 \\
(0.0 \%)\end{array}$ & $\begin{array}{c}0 \\
(0.0 \%)\end{array}$ & 1.26 & 0.50 \\
\hline vi. & Edited books & $\begin{array}{c}157 \\
(80.1 \%)\end{array}$ & $\begin{array}{c}39 \\
(19.9 \%)\end{array}$ & $\begin{array}{c}0 \\
(0.0 \%)\end{array}$ & $\begin{array}{c}0 \\
(0.0 \%)\end{array}$ & $\begin{array}{c}0 \\
(0.0 \%)\end{array}$ & 1.20 & 0.40 \\
\hline vii. & Monographs & $\begin{array}{c}174 \\
(88.8 \%)\end{array}$ & $\begin{array}{c}19 \\
(9.7 \%)\end{array}$ & $\begin{array}{c}0 \\
(0.0 \%)\end{array}$ & $\begin{array}{c}0 \\
(0.0 \%)\end{array}$ & $\begin{array}{c}3 \\
(1.5 \%)\end{array}$ & 1.16 & 0.56 \\
\hline viii. & Textbooks & $\begin{array}{c}164 \\
(83.7 \%)\end{array}$ & $\begin{array}{c}29 \\
(14.8 \%)\end{array}$ & $\begin{array}{c}3 \\
(1.5 \%)\end{array}$ & $\begin{array}{c}0 \\
(0.0 \%)\end{array}$ & $\begin{array}{c}0 \\
(0.0 \%)\end{array}$ & 1.18 & 0.42 \\
\hline ix. & Technical reports & $\begin{array}{c}145 \\
(74.0 \%)\end{array}$ & $\begin{array}{c}34 \\
(17.3 \%)\end{array}$ & $\begin{array}{c}13 \\
(6.6 \%)\end{array}$ & $\begin{array}{c}0 \\
(0.0 \%)\end{array}$ & $\begin{array}{c}4 \\
(2.0 \%)\end{array}$ & 1.39 & 0.79 \\
\hline $\mathbf{x}$. & $\begin{array}{l}\text { Patent and certified } \\
\text { invention } \\
\text { Grand Mean }\end{array}$ & $\begin{array}{c}173 \\
(87.8 \%)\end{array}$ & $\begin{array}{c}9 \\
(4.6 \%)\end{array}$ & $\begin{array}{c}14 \\
(7.1 \%)\end{array}$ & $\begin{array}{c}0 \\
(0.0 \%)\end{array}$ & $\begin{array}{c}0 \\
(0.0 \%)\end{array}$ & $\begin{array}{l}1.19 \\
1.48\end{array}$ & 0.55 \\
\hline
\end{tabular}

Source: Field Survey, 2020

Decision rule: $\leq 1.99=$ Very Low, $2.00-2.99=$ Low, 3.00-3.99 $=$ High, $4.00-5.00=$ Very High

Objective Two: The level of awareness and satisfaction towards open access use

Respondents were asked questions to determine their awareness and satisfaction towards open access resource use. The details of the analysis are found in Table 4.

Table 4. Awareness of and Satisfaction with Open Access Resources

\begin{tabular}{ll}
\hline Awareness of open access resources & Frequency (Percentage) \\
\hline Fully Aware & $83(42.3 \%)$ \\
Aware & $74(37.8 \%)$ \\
Somewhat Aware & $39(19.9 \%)$ \\
& \\
Satisfaction towards the use of open access resources & \\
Fully satisfied & $37(18.9 \%)$ \\
Satisfied & $139(70.9 \%)$ \\
Not Satisfied & $20(10.2 \%)$ \\
\hline
\end{tabular}

Source: Field Survey, 2020 
Table 4 presents responses on the awareness of open access resources and the satisfaction level of respondents. It reveals that $83(42.3 \%)$ of respondents are fully aware of open access resources, $74(37.8 \%)$ are aware whiles 39 $(19.9 \%)$ of respondents are somewhat aware of open access resources. This indicates a high level of awareness of open access resources. Again, it reveals that only $37(18.9 \%)$ are fully satisfied with the open access resources with as many as $139(70.9 \%)$ being satisfied and finally $20(10.2 \%)$ not satisfied with the open access resources. It is concluded generally that the faculty members are satisfied with the open access resources but not fully satisfied with them.

Objective Three: The extent to which faculty members use open access electronic resources.

Respondents were asked questions to determine their open access usage behaviour or pattern, satisfaction, extent of use of various open access resources and repositories as well as the rate at which they use open access resources. The details of the analysis are found in Table 5 .

In Table 5, analysis of the extent to which faculty members use open access resources is presented using a five-point scale which is from "Never" to "Always". Here, the extent of use of open access journals, open access repositories, open access databases, open access e-books, personal blogs and websites by faculty members is assessed. Details of the responses are summarized in Table 5.

Table 5. Extent to Which Faculty Members use Open Access Resources

\begin{tabular}{|c|c|c|c|c|c|c|c|c|}
\hline $\mathbf{S} / \mathbf{N}$ & Open Access Resources & Always & Frequently & Sometimes & $\begin{array}{c}\text { As and } \\
\text { when } \\
\text { needed }\end{array}$ & Never & Mean & $\begin{array}{l}\text { Standard } \\
\text { Deviation }\end{array}$ \\
\hline 1. & $\begin{array}{l}\text { DOAJ (Directory of Open } \\
\text { Access Journals) }\end{array}$ & $\begin{array}{c}25 \\
(12.8 \%)\end{array}$ & $\begin{array}{c}55 \\
(28.1 \%)\end{array}$ & $\begin{array}{c}67 \\
(34.2 \%)\end{array}$ & $\begin{array}{c}35 \\
(17.9 \%)\end{array}$ & $\begin{array}{c}14 \\
(7.1 \%)\end{array}$ & 3.21 & 1.10 \\
\hline 2. & Open Access Library & $\begin{array}{c}11 \\
(5.6 \%)\end{array}$ & $\begin{array}{c}66 \\
(33.7 \%)\end{array}$ & $\begin{array}{c}68 \\
(34.7 \%)\end{array}$ & $\begin{array}{c}34 \\
(17.3 \%)\end{array}$ & $\begin{array}{c}17 \\
(8.7 \%)\end{array}$ & 3.10 & 1.04 \\
\hline 3. & SAGE & $\begin{array}{c}13 \\
(6.6 \%)\end{array}$ & $\begin{array}{c}64 \\
(32.7 \%)\end{array}$ & $\begin{array}{c}46 \\
(23.5 \%)\end{array}$ & $\begin{array}{c}45 \\
(23.0 \%)\end{array}$ & $\begin{array}{c}28 \\
(14.3 \%)\end{array}$ & 2.94 & 1.18 \\
\hline 4. & Open J Gate & $\begin{array}{c}0 \\
(0.0 \%)\end{array}$ & $\begin{array}{c}29 \\
(14.8 \%)\end{array}$ & $\begin{array}{c}50 \\
(25.5 \%)\end{array}$ & $\begin{array}{c}50 \\
(25.5 \%)\end{array}$ & $\begin{array}{c}67 \\
(34.2 \%)\end{array}$ & 2.21 & 1.07 \\
\hline 5. & $\begin{array}{l}\text { Open Access Portals of } \\
\text { payment journals }\end{array}$ & $\begin{array}{c}3 \\
(1.5 \%)\end{array}$ & $\begin{array}{c}60 \\
(30.6 \%)\end{array}$ & $\begin{array}{c}41 \\
(20.9 \%)\end{array}$ & $\begin{array}{c}28 \\
(14.3 \%)\end{array}$ & $\begin{array}{c}64 \\
(32.7 \%)\end{array}$ & 2.54 & 1.27 \\
\hline 6. & $\begin{array}{l}\text { OAJSE (Open Access Journal } \\
\text { Search Engine) }\end{array}$ & $\begin{array}{c}18 \\
(9.2 \%)\end{array}$ & $\begin{array}{c}39 \\
(19.9 \%)\end{array}$ & $\begin{array}{c}53 \\
(27.0 \%)\end{array}$ & $\begin{array}{c}39 \\
(19.9 \%)\end{array}$ & $\begin{array}{c}47 \\
(24.0 \%)\end{array}$ & 2.70 & 1.28 \\
\hline 7. & $\begin{array}{l}\text { MDPI (Management } \\
\text { Development and Productivity } \\
\text { Institute }\end{array}$ & $\begin{array}{c}6 \\
(3.1 \%)\end{array}$ & $\begin{array}{c}19 \\
(9.7 \%)\end{array}$ & $\begin{array}{c}36 \\
(18.4 \%)\end{array}$ & $\begin{array}{c}49 \\
(25.0 \%)\end{array}$ & $\begin{array}{c}86 \\
(43.9 \%)\end{array}$ & 2.03 & 1.14 \\
\hline 8. & $\begin{array}{l}\text { Open DOAR (The Directory } \\
\text { of Open Access Repositories) }\end{array}$ & $\begin{array}{c}9 \\
(4.6 \%)\end{array}$ & $\begin{array}{c}44 \\
(22.4 \%)\end{array}$ & $\begin{array}{c}54 \\
(27.6 \%)\end{array}$ & $\begin{array}{c}40 \\
(20.4 \%)\end{array}$ & $\begin{array}{c}49 \\
(25.0 \%)\end{array}$ & 2.61 & 1.21 \\
\hline 9. & $\begin{array}{l}\text { NDLTD (Networked Digital } \\
\text { Library of Thesis and } \\
\text { Dissertation) }\end{array}$ & $\begin{array}{c}7 \\
(3.6 \%)\end{array}$ & $\begin{array}{c}33 \\
(16.8 \%)\end{array}$ & $\begin{array}{c}78 \\
(39.8 \%)\end{array}$ & $\begin{array}{c}19 \\
(9.7 \%)\end{array}$ & $\begin{array}{c}59 \\
(30.1 \%)\end{array}$ & 2.54 & 1.19 \\
\hline 10. & $\begin{array}{l}\text { OCW (Open Courseware, } \\
\text { MIT) }\end{array}$ & $\begin{array}{c}3 \\
(1.5 \%)\end{array}$ & $\begin{array}{c}31 \\
(15.8 \%)\end{array}$ & $\begin{array}{c}57 \\
(29.1 \%)\end{array}$ & $\begin{array}{c}50 \\
(25.5 \%)\end{array}$ & $\begin{array}{c}55 \\
(28.1 \%)\end{array}$ & 2.37 & 1.10 \\
\hline 11. & $\begin{array}{l}\text { ERIC database (Educational } \\
\text { Research Information Center) }\end{array}$ & $\begin{array}{c}15 \\
(7.7 \%)\end{array}$ & $\begin{array}{c}56 \\
(28.6 \%)\end{array}$ & $\begin{array}{c}54 \\
(27.6 \%)\end{array}$ & $\begin{array}{c}22 \\
(11.2 \%)\end{array}$ & $\begin{array}{c}49 \\
(25.0 \%)\end{array}$ & 2.83 & 1.30 \\
\hline 12. & e-books & $\begin{array}{c}55 \\
(28.1 \%)\end{array}$ & $\begin{array}{c}70 \\
(35.7 \%)\end{array}$ & $\begin{array}{c}48 \\
(24.5 \%)\end{array}$ & $\begin{array}{c}20 \\
(10.2 \%)\end{array}$ & $\begin{array}{c}3 \\
(1.5 \%)\end{array}$ & 3.79 & 1.02 \\
\hline 13. & Institutional Websites & $\begin{array}{c}43 \\
(21.9 \%)\end{array}$ & $\begin{array}{c}94 \\
(48.0 \%)\end{array}$ & $\begin{array}{c}32 \\
(16.3 \%)\end{array}$ & $\begin{array}{c}20 \\
(10.2 \%)\end{array}$ & $\begin{array}{c}7 \\
(3.6 \%)\end{array}$ & 3.74 & 1.03 \\
\hline \multirow[t]{2}{*}{14.} & Personal Blogs and Website & $\begin{array}{c}16 \\
(8.2 \%)\end{array}$ & $\begin{array}{c}38 \\
(19.4 \%)\end{array}$ & $\begin{array}{c}56 \\
(28.6 \%)\end{array}$ & $\begin{array}{c}61 \\
(31.1 \%)\end{array}$ & $\begin{array}{c}25 \\
(12.8 \%)\end{array}$ & 2.79 & 1.14 \\
\hline & & & & & & & 2.81 & 1.15 \\
\hline
\end{tabular}

Source: Field Survey, 2020 
Decision Rule: Very Low Extent: $0.00-0.99$, Low Extent: 1.00 - 1.99, Considerable Extent: 2.00 - 2.99, High Extent: 3.00 - 3.99, Very High Extent: 4.00 - 5.00

From Table 5, a grand mean of 2.81 indicates faculty members of Dartum University use open access resources to a considerable extent. The table shows a high extent of use for e-books (mean 3.79), institutional websites (mean 3.74), DOAJ (mean 3.12), Open Access Library (3.10) and a considerable usage of all the other open access resources presented.

Objective Four: The purpose for which faculty members use open access electronic resources.

Respondents were asked to indicate their agreement or disagreement to some purposes of using open access resources. Table 6 provides the details of the responses.

Table 6. Purpose of Using Open Access Resources

\begin{tabular}{llcccc}
\hline S/N & Purpose & $\begin{array}{c}\text { Strongly } \\
\text { Agree }\end{array}$ & Agree & Disagree & $\begin{array}{c}\text { Strongly } \\
\text { Disagree }\end{array}$ \\
\hline 1. & To do course work & 58 & 116 & 19 & 3 \\
2. & Updating subject knowledge & $(29.6 \%)$ & $(59.2 \%)$ & $(9.7 \%)$ & $(1.5 \%)$ \\
& & 80 & 109 & 7 & 0 \\
3. & Research work & $(40.8 \%)$ & $(55.6 \%)$ & $(3.6 \%)$ & $(0.0 \%)$ \\
& & 103 & 93 & 0 & 0 \\
4. & Writing Papers/Articles & $(52.6 \%)$ & $(47.4 \%)$ & $(0.0 \%)$ & $(0.0 \%)$ \\
& & 73 & 120 & 3 & 0 \\
5. & Teaching & $(37.2 \%)$ & $(61.2 \%)$ & $(1.5 \%)$ & $(0.0 \%)$ \\
& & 67 & 116 & 13 & 0 \\
6. & Other academic activities & $(34.2 \%)$ & $(59.2 \%)$ & $(6.6 \%)$ & $(0.0 \%)$ \\
& & 49 & 127 & 13 & 7 \\
7. & Preparation of lecture notes & $(25.0 \%)$ & $(64.8 \%)$ & $(6.6 \%)$ & $(3.6 \%)$ \\
& & 51 & 121 & 19 & 5 \\
\hline
\end{tabular}

Source: Field Survey, 2020

From Table 6, $174(88.8 \%)$ of respondents strongly agreed and agreed that they use open access to do course work, 189 (96.4\%) strongly agreed and agreed that they use open access to update subject knowledge, all respondents strongly agreed or agreed that they use open access for research work, 98.4\%, 93.4\%, 89.8\% and $87.7 \%$ of respondents agreed or strongly disagreed that they use open access for writing papers/articles, teaching, other academic activities and preparation of lecture notes respectively. It can be concluded generally that the respondents agreed to the use of open access resources for course work, updating subject knowledge, research work, writing papers and the other activities.

Objective Five: The challenges that faculty members face in the use of open access e-resources. Respondents were asked to find out some challenges of the use of open access e-resources. The questions demanded the respondents to indicate their agreement or disagreement to four statements and questions, which were presented in a Likert-scale format. Table 7 provides the details of the responses.

From table 7, four challenges of open access were identified based on the responses from the respondents. In terms of education, $72.9 \%$ of respondents affirmed that the librarians at Dartum University do not provide education to faculty, administrators and others about the benefits of open access. With regard to predatory journals, $62.3 \%$ agreed and strongly agreed that open access has contributed to the rise of predatory journals. In relation to ICT, $69.9 \%$ affirmed that poor ICT infrastructure has made the development of institutional repositories unsustainable and $72 \%$ of respondents were in agreement that inadequate skills to navigate the internet exacerbates the constraints to the use of open access. 
Table 7. Challenges to Faculty Members' Use of Open Access e-resources

\begin{tabular}{llcccc}
\hline S/N & \multicolumn{1}{c}{ Items } & $\begin{array}{c}\text { Strongly } \\
\text { Agree }\end{array}$ & Agree & $\begin{array}{c}\text { Disagree } \\
\text { Strongly } \\
\text { Disagree }\end{array}$ \\
\hline 1. & $\begin{array}{l}\text { The librarians in my institution do not provide } \\
\text { education to faculty, administrators and others about } \\
\text { the benefits of open access. }\end{array}$ & $\begin{array}{c}70 \\
(35.7 \%)\end{array}$ & 73 & 50 & 3 \\
$(37.2 \%)$ & $(25.5 \%)$ & $(1.5 \%)$ \\
2. $\quad \begin{array}{l}\text { Poor ICT infrastructure has made development of } \\
\text { institutional repositories unsustainable. }\end{array}$ & 36 & 101 & 52 & 7 \\
3. $\quad \begin{array}{l}\text { Inadequate skills to navigate the internet exacerbates } \\
\text { the constraints to the use of open access. }\end{array}$ & 36 & 105 & 33 & $(3.6 \%)$ \\
4. $\quad \begin{array}{l}\text { My institution has adequate ICT infrastructure } \\
\text { and promotes the use of open access resources. }\end{array}$ & 32 & $(16.4 \%)$ & $(53.6 \%)$ & $(16.8 \%)$ & $(11.2 \%)$ \\
\end{tabular}

Source: Field Survey, 2020

\subsection{Testing of Hypothesis}

Tables 8 and 9 present the regression results of testing the hypothesis. A multiple regression analysis was used with the help of the SPSS. The factors which were considered in the testing of hypothesis included the level of awareness and satisfaction, the extent of use of open access electronic resources, the purpose for using open access electronic resources and the related challenges in the use of open access e-resources

$\mathrm{H}_{0}$ : The use of open access electronic resources will not significantly influence the research productivity of Dartum University faculty members.

Table 8. Regression Model Summary

\begin{tabular}{lccccc}
\hline \multirow{2}{*}{ Model } & \multicolumn{5}{c}{ Model Summary } \\
\cline { 2 - 6 } & $\mathrm{R}$ & R Square & Adjusted R Square & Std. Error of the Estimate & Durbin-Watson \\
\hline $\mathbf{x 1}$ & $.589^{\mathrm{a}}$ & .347 & .297 & 1.01572 & 1.929 \\
\hline
\end{tabular}

Table 9. Anova

\begin{tabular}{lccccc}
\hline Model & \multicolumn{5}{c}{ Anova } \\
\cline { 2 - 6 } & Sum of Squares & df & Mean Square & F & Sig. \\
\hline Regression & 99.263 & 14 & 7.090 & 6.872 & $.000^{\text {a }}$ \\
Residual & 186.737 & 181 & 1.032 & & \\
Total & 286.000 & 195 & & & \\
\hline
\end{tabular}

Predictors: (Constant), Blogs/Websites, Open Access Portals of Payment Journals, e-books, SAGE, Open Access Library, Institutional Websites, NDLTD (Networked Digital Library of Thesis and Dissertation), OAJSE (Open Access Journal Search Engine), Open J Gate, OCW (Open Courseware, MIT), ERIC database (Educational Research Information Center), DOAJ (Directory of Open Access Journals), Open DOAR (Directory of Open Access Repositories), MPDI (Management Development and Productivity Issue)

Dependent Variable: How many publications have you produced?

A standard multiple regression was conducted using the enter method to determine if the use of open access resources will significantly influence research productivity in Dartum University. The regression analysis included number of publications produced as the dependent variable and Directory of Open Access Journals (DOAJ), Open Access Library, SAGE, Open J Gate, Open Access Portals of payment journals, OAJSE (Open Access Journal Search Engine), MDPI (Management Development and Productivity Institute), NDLTD (networked Digital Library of Thesis and Dissertation), OCW (Open Courseware, MIT), ERIC database (Educational Research Information Center), e-books, Institutional Websites and Personal Blogs and Websites as the independent variables. The Regression results indicate that the overall model significantly predicts faculty members productivity as seen in Table $8\left[R^{2}=0.347, R^{2}\right.$ adj $\left.=0.297, F(14,181)=6.872, p<0.005\right]$. This model accounts for $34.7 \%$ variance in faculty members' productivity. A summary of regression coefficients is presented in Table 10 and indicates that eight out of 
fourteen open access electronic resource variables have $p$-values greater than an $\alpha$-value of 0.05 . They imply that we fail to reject the null hypothesis and conclude that eight out of fourteen open access electroniic resources will not significantly influence research productivity. On the other hand, six out of fourteen open access electronic resource variables have $p$-values less than $\alpha=0.05$. They imply that we reject the null hypothesis and conclude that six out of fourteen open access electronic resources will significantly influence research productivity. Since $57.14 \%$ of the resources will not significantly influence research productivity and $42.86 \%$ significantly influence research productivity by simple majority most of open access electronic resources will not significantly influence research productivity.

Table 10. Summary of Coefficient for Model Variables

\begin{tabular}{|c|c|c|c|c|}
\hline Source & B & Beta & $\mathbf{t}$ & $\mathbf{p}$ \\
\hline DOAJ (Directory of Open Access Journals) & .285 & .259 & 2.865 & $<.005$ \\
\hline Open Access Library & -.163 & -.140 & -1.658 & .099 \\
\hline SAGE & .385 & .376 & 4.870 & .000 \\
\hline Open J Gate & .193 & .171 & 2.124 & $<.035$ \\
\hline Open Access Portals of Payment Journals & .153 & .161 & 1.863 & .064 \\
\hline OAJSE (Open Access Journal Search Engine) & -.140 & -.148 & -1.790 & .075 \\
\hline MPDI (Management Development and Productivity Issue) & .027 & .025 & .262 & .793 \\
\hline Open DOAR (Directory of Open Access Repositories) & .006 & .006 & .060 & .952 \\
\hline NDLTD (Networked Digital Library of Thesis and Dissertation) & -.397 & -.389 & -4.454 & .000 \\
\hline OCW (Open Courseware, MIT) & -.165 & -.150 & -1.792 & .075 \\
\hline ERIC database (Educational Research Information Center) & -.220 & -.236 & -2.787 & $<.006$ \\
\hline e-books & .353 & .296 & 4.303 & .000 \\
\hline Institutional Websites & .031 & .026 & .386 & .700 \\
\hline Blogs/Websites & -.096 & -.091 & -1.242 & .216 \\
\hline
\end{tabular}

\subsection{Discussion of Findings}

The study was carried out with five key items as guiding principles: the research productivity level of faculty, the level of awareness and satisfaction, the extent of use of open access electronic resources, the purpose for using open access electronic resources and the challenges of use of open access e-resources. It was found out that research productivity level of faculty was very low (14.8\%) with low open access publication $(3.6 \%)$ and with low publications in subscription-based journals (2\%). These findings confirm Lertputtarak's (2008) and Alabi and Mohammed's (2018) research findings that research productivity in Africa is relatively low. They also fall within Maasen's (2015) description of African universities as lagging behind as far as research productivity is concerned despite the presence of highly productive scholars and academics.

The study also found out that the use of open access resources was to a considerable extent with a grand mean of 2.81. There was a high extent of use of e-books (3.79), institutional websites (3.74), use of DOAJ (3.12) and open access library use (3.10). The extent of use of open access electronic resources was therefore very high. These findings are also in line with the Social Exchange Theory explained by Kim (2011). Kim's explanation shows that The Social Exchange Theory helps in the understanding of how researchers and faculty members share information by means of open access using the cost and benefits analysis. The high mean scores and the extent of use of e-books shows taht faculty members were using open access for their publications as the benefits of using open access might have outweighed the costs. The high mean scores and the extent of use of open access are also in line with the unified theory of acceptance and use of technology (Venkatesh, Morris, Davis \& Davis, 2003) as the faculty members were influenced by the performance expectancy, effort expectancy, social influence and facilitating conditions (Alwahaishi \& Vaclav, 2013)

The respondents were fully aware of the use of open access resources (42.3\%), but those who were just aware of the use of open access resources gave $37.8 \%$. In terms of respondents' satisfaction, it was found that they were generally satisfied but not fully satisfied.

The purpose for the use of open access e-resources was also very high as the percentages for both Strongly Agree and Agree were very high. For instance, the respondents agreed in using open access for course work (59.2\%), for updating subject knowledge (55.6\%), for research work (47.1\%), for writing articles $(61.2 \%)$, for teaching $(59.2 \%)$, 
for preparation of lecture notes (61.7) and for other academic activities (64.8\%). The purpose for using open access e-resoures was therefore very encouraging.

The respondents agree on enormous challenges as they disagreed that institutions have insitutional repository $(67.7 \%)$. With regard to plagiarism, it was agreed that open access can be plagiarised $(55.1 \%)$, and it is vulnerable to copyright issues $(62.2 \%)$, and finally, libririans do not normally provide education to faculty on the use of e-resources $(72.9 \%)$.

Finally, the fourteen independent variables were found to have influenced faculty's productivity level. The null hypothesis which says that the use of open access electronic resources will not significantly influence the research productivity of faculty members was rejected but failed to reject the alternate hypothesis that the use of open access electronic resources will significantly influence the research productivity of faculty members.

\section{Conclusion}

Universities play a vital role in nation building through research by faculty members. Nations with low research productivity will therefore continue to lag behind the world with African countries included. It is, therefore, important for nations and universities to commit adequate resources including ICT infrastructure to research development. This article, just like other reviewed researches in Africa, concludes on findings of low productivity among faculty members even in the open access era. The article revealed that open access resource use has a weak significant influence on research productivity among faculty members at Dartum University. It is therefore necessary for faculty members to be provided with the right education and resources to help improve research productivity. Challenges like poor ICT infrastructure, poor navigation skills, absence of institutional repositories and others which make research difficult should gradually become a thing of the past.

\subsection{Recommendations of the Study}

Based on the findings of the research, the following recommendations are proposed:

i Efforts to promote research productivity must be intensified with the government providing support to its institutions.

ii African universities including Dartum University should have institutional repositories which support open access and its research activities in place.

iii Librarians must perform the duty of educating faculty, administrators and others on the benefits of open access use.

iv Developing ICT infrastructure should be an important objective of universities in Africa with support from governments as ICT remains the foundation for research and other activities.

\subsection{Contribution to Knowledge}

With the growing need for electronic resources and open access resources, it is expedient to understand its role in the educational system. The role of open access resources in research can no longer be downplayed with the ever-increasing number of journals and repositories which support open access. The growing need for research which is seen as a tool for nation and economic building with universities playing the central role has been highlighted. The study has also brought to light the role of open access resources in the development of research productivity especially in the developing world by highlighting the various purposes faculty members use open access and the extent to which it is used in research. The challenges associated with the use of open access resources have also been expatiated in the study.

\subsection{Suggestions for Further Study}

The article revealed that research productivity is low despite the high awareness of open access. Much study needs to be conducted to identify the reasons research productivity continues to be low despite the growing awareness of open access resources. The study also focused on Dartum University, a private university in Ghana. Further studies could be conducted considering public universities, technical universities and other private universities. Future research can also venture into open access use and research productivity focusing on age and gender.

\subsection{Implications of the Study}

The awareness level of the use of open access resources by faculty members was not very high hence very low productivity level. Again, librarians have been accused of not providing education to faculty. The implication is that 
high productivity level of faculty members is dependent on their education in order to create in them awareness and satisfaction. In this regard, librarians have a very significant role to play. Research, teaching and community service are three interplay of factors that keep a university vibrant so if the research element is very low then the implication is that teaching and community service will be ultimately affected.

\section{References}

Abramo, G., \& D'Angelo, C. A. (2014, March 19). How do you define and measure research productivity? Scientometrics, 101, 1129-1144. https://doi.org/10.1007/s11192-014-1269-8

Alabi, G., \& Mohammed, I. (2018). Research and PhD Capacities in Sub-Saharan Africa. Deutscher Akademischer Austauschdienst.

Altback, P. G. (2014, July 18). What counts for academic productivity in research universities? University World News.

Alwahaishi, S., \& Vaclav, S. (2013). Consumers' Acceptance and Use of Information and Communications Technology: A UTAUT and Flow Based Theoretical Model. Journal of Technology Management \& Innovation, 8(2), 61-73. https://doi.org/10.4067/S0718-27242013000200005

Brew, A., Boud, D., Namgung, S. U., Lucas, L., \& Crawford, K. (2015, August 9). Research Productivity and Academics' conception of research. Higher Education, 71, 681-697. https://doi.org/10.1007/s10734-015-9930-6

Crossman, A. (2020, January 14). Understanding Social Exchange Theory. ThoughtCo.

Guedon, J. C. (2015). Open Access: Towards the Internet of the Mind. Budapest Open Access Initiative

Iddris, F. (2017, September). Examining the Research output of Lecturers in Ghana. 1st International Conference on Competerncy-Based Training and Research (pp. 207-215). Winneba: University of Education.

Kankanhalli, A., Tan, B. C., \& Wei, K. K. (2005). Contributing Knowledge to Electronic Knowledge Repositories: An Empirical Investigation. MIS Quarterly, 29(1), 113-143. https://doi.org/10.2307/25148670

Kumar, S. A., \& Bansal, J. (2008). The Impact of Open Access on Scholarly Communication and its Future. Library Herald, 46(2), 91-102.

Lertputtarak, S. (2008). An Investigation of Factors Related to Research Productivity in Pulic Universitys' in Thailand: A Case Study. Victoria University Research Repository, Victoria University.

Maasen, P. (2015, March 6). Research Productivity at flagship African Universities. University World News.

Morrison, H. (2012). Freedom for Scholarship in the Internet Age (PhD Dissertation). Simon Fraser University, Britain.

Musa, A. U., Sanusi, A. B., Yusuf, S., \& Shittu, M. (2015, February). Open Access Scholarly Publishing: A Chance for Maximization of Research Productivity among Academics in Nigerian Federal Universities. Journal of Humanities and Social Science, 20(2), 1-9.

Ogbomo, E. F. (2010). Publication Output of Librarians in Tertiary Institutions: A Case Study of Delta State University. Library Philosophy and Practice (e-journal), 1-10.

Osahon, O. J., \& Kingsley, O. (2016). Statistical approach to the link between internal service quality and employee job satisfaction: A case study. American Journal of Applied Mathematics and Statistics, 4(6), 178-184. https://doi.org/10.12691/ajams-4-6-3

Pinfield, S. (2008). Libraries and Open Access: The Implications of Open Access Publishing and Dissemination for Libraries in Higher Education Institutions. In Earnshaw R., Vince J. (Eds.), Digital Convergence-Libraries of the Future. London: Springer.

Ram, S., \& Paliwal, N. (2016, July). Management of University Research Publication: A Case Study of JUIT Publication Database. DESIDOC Journal of Library and Information Technology, 36(4), 212-219. https://doi.org/10.14429/djlit.36.4.9912

Saric, J., Utzinger, J., \& Bonfoh, B. (2018, August 23). Research Productivity and main publishing institutions in Cote D'Ivoire, 2000-2016. Globalization and Health, 14, 88. https://doi.org/10.1186/s12992-018-0406-1

Suber, P. (2015). Open Access Overview: Focusing on open access to peer-reviewed research articles and their preprints. 
Utulu, S. (2005). Role of Journals in Developing Emerging Scholars in Library and Information Science. Proceedings of the Conference held at Conference Centre University of Ibadan, Nigeria: Third World Information Service Limited, (pp. 137-147).

Venkatesh, V., Morris, M. G., \& Davis, G. B. (2003). User Acceptance of Information Technology: Toward a Unified View. MIS Quarterly, 27(3), 425-478. https://doi.org/10.2307/30036540

Yamane, T. (1967). Statistics: An Introductory Analysis (2nd ed.). New York: Harper and Row.

Zhou, L. L., Owusu-Marfo, J., Antwi, H. A., Antwi, M. O., Kachie, A. D., \& Ampong-Wireko, S. (2019, November 21). Assessment of the social influence and facilitating conditions that support nurses' adoption of hospital electronic information management systems (HEIMS) in Ghana using the unified theory of acceptance and use of technology (UTAUT) model. BMC Medical Informatics and Decision Making, $19,230$. https://doi.org/10.1186/s12911-019-0956-z

\section{Copyrights}

Copyright for this article is retained by the author(s), with first publication rights granted to the journal.

This is an open-access article distributed under the terms and conditions of the Creative Commons Attribution license (http://creativecommons.org/licenses/by/4.0/). 